\title{
Prediksi Jumlah Produksi Tas Pada Home Industri Body Star Kudus Menggunakan Fuzzy Tsukamoto
}

\section{Bag Production Estimation at Body Star Kudus Home Industry using Fuzzy Tsukamoto}

\author{
Muchamad Afif $^{1}$, Hanny Haryanto $^{2}$, Yuniarsi Rahayu ${ }^{3}$, Edy Mulyanto $^{4}$ \\ Program Studi Teknik Informatika - S1 \\ Fakultas Ilmu Komputer \\ Universitas Dian Nuswantoro, Jl. Nakula 1 No. 5-11, Semarang \\ 111201206926@mhs.dinus.ac.id ${ }^{1}$, hanny.haryanto@dsn.dinus.ac.id ${ }^{2}$, \\ yuniarsi.rahayu@dsn.dinus.ac.id ${ }^{3}, \underline{\text { edy.mulyanto@dsn.dinus.ac.id }}^{3}$
}

\begin{abstract}
Abstrak
Kesalahan jumlah produksi adalah masalah yang sering terjadi dalam home industy. Kesalahan ini menyebabkan kerugian karena jumlah produksi yang terlalu banyak akan berakibat pada penumpukan barang dan produksi yang terlalu sedikit menyebabkan tidak bisa dipenuhinya permintaan dari pasar. Permasalahan ini juga dialami oleh home industry Body Star Kudus dalam memproduksi tas. Tujuan dari penelitian ini adalah memecahkan masalah tersebut dan diharapkan bisa membantu produsen dalam memprediksi jumlah tas perbulan. Metode yang digunakan dalam penelitian ini adalah metode Fuzzy Tsukamoto. Metode ini dipilih karena Fuzzy Tsukamoto memiliki kelebihan dalam penerapan pada data yang sederhana dan pemrosesan yang ringan. Parameter input yang digunakan adalah data retur, data penjualan dan data sisa. Hasil dari penelitian menunjukkan bahwa ada beberapa prediksi yang dihasilkan mempunyai akurasi yang kurang bagus, namun secara keseluruhan memiliki akurasi yang dapat diterima.
\end{abstract}

Kata Kunci - kecerdasan buatan, prediksi, Fuzzy Tsukamoto, jumlah produksi.

\begin{abstract}
Production error is a common problem in home industy. This error causes a loss because of the amount of production that too much will result in the accumulation of goods and the production is too little causes can not fulfill the demand of the market. This problem is also shared by the home industry Body Star Kudus in producing handbags. The purpose of this research is to solve the problem and is expected to help producers predict the number of bags per month. The method used in this research is Fuzzy Tsukamoto method. This method was chosen because Fuzzy Tsukamoto has advantages in the application on simple data and lightweight processing. The input parameters used are data returns, sales data and residual data. The results of the study indicate that some predictions have poor accuracy, but overall have an acceptable accuracy.
\end{abstract}

Keywords - artificial intelligence, prediction, Fuzzy Tsukamoto, production number.

\section{PENDAHULUAN}

Tas merupakan kebutuhan aktivitas sehari-hari bagi setiap manusia dalam berpergian. Hampir semua kalangan baik perempuan, laki-laki orang tua, dewasa, remaja maupun anakanak mempunyai lebih dari satu tas [1]. Home industri Body Star Kudus merupakan salah satu 
yang bergerak dibidang produksi tas yang berada di Kabupaten Kudus. Penelitian yang berjudul "Pengembangan Industri Kecil Tas Di Kecamatan Kabupaten Kudus" [2] menjelaskan bahwa industri tas kecil yang menonjol di Kabupaten Kudus. Karena keberadaan industri kecil tas ini sangat membantu dalam penyerapan tenaga sekitar sehingga masyarakatnya bisa sejahtera, karena membutuhkan tenaga kerja yang cukup banyak dan tidak membutuhkan pendidikan yang tinggi. Dalam penelitian ini juga dijelaskan tentang produksi tas, Produksi tas yaitu suatu proses tas kombinasi dan koordinasi material-material, kekuatan-kekuatan, model-model (input, faktor, sumberdaya atau jasa-jasa produksi) dalam pembuatan suatu barang atau jasa (output atau produk) yang dihasilkan suatu produk tas yang kualitasnya baik. Permasalahan yang umum terjadi adalah kesulitan untuk menentukan jumlah produksi. Kesalahan yang terjadi dalam menentukan jumlah produksi dapat menyebabkan kerugian karena jumlah produksi yang terlalu banyak akan berakibat pada penumpukan barang dan produksi yang terlalu sedikit menyebabkan tidak bisa dipenuhinya permintaan dari pasar. Untuk dapat mengatasi permasalahan tersebut maka diperlukan prediksi perbulan, sehingga dapat meminimalkan kesalahan jumlah produksi tas.

Penelitian pada tahun 2012 oleh [3] yang berjudul tentang"Perbandingan Model Chen Dan Model Lee Pada Metode Fuzzy Time Series Untuk Prediksi Harga Emas" menjelaskan tentang ANFIS sebagai suatu teknik optimasi yang menggabungkan Neural Network dan Fuzzy Logic, FTS adalah metode prediksi data yang menggunakan prinsip-prinsip fuzzy sebagai dasarnya. Penerapan Fuzzy yang digunakan untuk prediksi jumlah produksi roti pada CV. Gendis Bakery dilakukan pada tahun 2015 oleh [4] menjelaskan tentang prediksi jumlah produksi roti dengan menggunakan Fuzzy Tsukamoto. Melalui prediksi ini perusahan dapat memprediksi jumlah produksi roti, Prediksi yaitu dari hasil kegiatan memprediksi atau meramal atau memperkirakan. Dalam penelitian ini juga menjelaskan tentang fuzzy logic. Fuzzy logic adalah sebuah metodologi "berhitung" dengan variabel kata-kata (linguistic variable), sebagai pengganti berhitung dengan bilangan, Fuzzy logic juga mempunyai kelebihan yang mudah dimengerti, memiliki toleransi data-data yang tidak tepat, mampu memodelkan fungsi-fungsi yang sangat kompleks. Dalam fuzzy logic ini fuzzy yang digunakan dalam memprediksi jumlah roti adalah fuzzy Tsukamoto karena fuzzy Tsukamoto memilki penalaran fuzzy yang cukup mudah untuk dipahami. Pada tahun 2014 penelitian yang berjudul tentang "Analisa Kelayakan Truk Pengangkut Material Alam PT.Arga Wastu Sluke-Rembang Menggunakan Fuzzy Logic Tsukamoto" [5] menjelaskan tentang Fuzzy Tsukamoto karena setiap nilai parameter konsekuen pada aturan yang berbentuk IF-THEN direpresentasikan dengan suatu himpunan fuzzy yang fungsi keanggotaanya monoton. Sebagai hasilnya keluaran hasil inferensi pada setiap aturan didefinisikan sebagai nilai yang tegas (crisp) berdasarkan kuat penyulutan aturan. Selanjutnya penelitian yang berjudul tentang "Penerapan Sistem Inferensi Fuzzy Dalam Menentukan Prioritas Heuristik Pada Aplikasi Game Fighting Sederhana" [6] menjelaskan bahwa tentang sistem inferensi fuzzy dalam menentukan prioritas heuristic aplikasi game. Karena perkembangan teknologi mengenai kecerdasan buatan telah berkembang pesat, beberapa aplikasi komputer telah menggunakan cabang dari ilmu komputer ini untuk memperbaiki kinerjanya. Salah satunya aplikasi multimedia, karena aplikasi multimedia menggambungkan berbagai media sebagai bagian dari sistemnya baik itu media visual,suara dan pemrograman di dalam aplikasi itu sendiri. Aplikasi multimedia juga diperuntukkan untuk hiburan yaitu aplikasi permainan disebut juga dengan game. Dalam penelitian ini juga menjelaskan tentang penerapan kecerdasan buatan pada aplikasi permainan, aplikasi-aplikasi permainan yang beredar saat ini telah menanamkan kecerdasan buatan yang lebih mutakhir dari Deep Blue, bahkan beberapa aplikasi permainan yang bertipe simulasi perang dan simulasi pesawat terbang digunakan oleh pihak militer untuk melatih para prajurit. Namun, kecerdasan buatan yang saat ini diterapkan oleh permainan-permainan komputer saat ini lebih menitik beratkan pada langkah-langkah yang kaku. sedangkan manusia, selain memiliki apa yang dinamakan kecerdasan, juga memiliki pola tingkah laku. Dengan menggunakan kemampuan untuk mempelajari pola pemainnya dari pemainya, sebuah komputer dapat memainkan sebuah permainan layaknya manusia. 
Dari penelitian sebelumnya didapat bahwa metode Fuzzy merupakan metode yang sering digunakan untuk melakukan prediksi, terutama untuk permasalahan yang memiliki data yang sederhana. Penelitian ini akan membahas tentang prediksi untuk jumlah produksi tas di home industry Body Star Kudus.

\section{METODE PENELITIAN}

Tahapan penelitian secara umum adalah studi literatur, penentuan kasus, pengumpulan data, desain sistem fuzzy, implementasi dan evaluasi seperti yang digambarkan dalam Gambar 1 berikut.

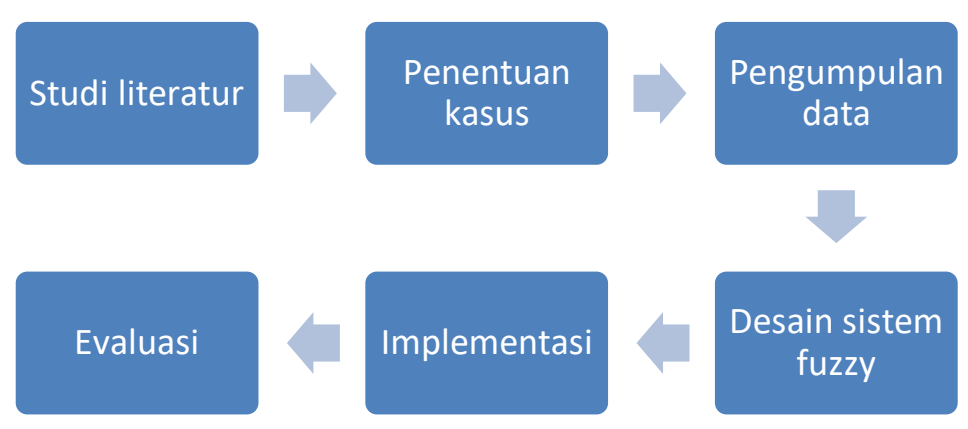

Gambar 1. Tahapan Penelitian

Penelitian ini dilakukan dengan menggunakan data tas ransel, tas slempang, dan data tas sekolah yang mengambil pada home Industri Body Star Kudus bulan januari-september tahun 2016. Data yang diperoleh dari home industri Body Star Kudus terdiri dari 4 data yaitu retur, sisa, penjualan, produksi Berikut adalah keterangan dan penjelasan data yang didapatkan.

Tabel 1 Data Retur Tas Januari - September 2016

\begin{tabular}{lccc}
\hline \multirow{2}{*}{ Bulan } & \multicolumn{3}{c}{ Jumlah Retur Tas (dalam unit) } \\
\cline { 2 - 4 } & Tas Ransel & Tas Slempang & Tas Sekolah \\
\hline Januari 2016 & 10 & 9 & 11 \\
\hline Februari 2016 & 12 & 11 & 14 \\
\hline Maret 2016 & 9 & 10 & 11 \\
\hline April 2016 & 7 & 9 & 6 \\
\hline Mei 2016 & 10 & 12 & 10 \\
\hline Juni 2016 & 6 & 7 & 7 \\
\hline Juli 2016 & 7 & 7 & 9 \\
\hline Agustus 2016 & 8 & 8 & 6 \\
\hline September 2016 & 6 & 7 & \\
\hline
\end{tabular}

Tabel 2 Data Penjualan Tas Januari - September 2016

\begin{tabular}{lccc}
\hline \multirow{2}{*}{ Bulan } & \multicolumn{3}{c}{ Jenis Tas } \\
\cline { 2 - 4 } & Tas Ransel & Tas Slempang & Tas Sekolah \\
\hline Januari 2016 & 1.440 & 1.200 & 1.680 \\
\hline Februari 2016 & 1.872 & 1.440 & 1.536 \\
\hline Maret 2016 & 1.584 & 1.920 & 1.776 \\
\hline April 2016 & 1.680 & 1.200 & 1.680 \\
\hline
\end{tabular}


Prediksi Jumlah Produksi Tas Pada Home Industri Body Star Kudus ...

\begin{tabular}{llll}
\hline Mei 2016 & 1.200 & 1.008 & 1.200 \\
\hline Juni 2016 & 2.256 & 2.112 & 2.064 \\
\hline Juli 2016 & 2.352 & 2.352 & 2.352 \\
\hline Agustus 2016 & 2.112 & 2.016 & 2.112 \\
\hline September 2016 & 1.440 & 1.200 & 1.440 \\
\hline
\end{tabular}

Tabel 3 Data Sisa Tas Januari - September 2016

\begin{tabular}{lccc}
\hline \multirow{2}{*}{ Bulan } & \multicolumn{3}{c}{ Jenis Tas } \\
\cline { 2 - 4 } & Tas Ransel & Tas Slempang & Tas Sekolah \\
\hline Januari 2016 & 230 & 231 & 85 \\
\hline Februari 2016 & 36 & 229 & 130 \\
\hline Maret 2016 & 87 & 182 & 133 \\
\hline April 2016 & 233 & 231 & 234 \\
\hline Mei 2016 & 230 & 180 & 230 \\
\hline Juni 2016 & 138 & 41 & 88 \\
\hline Juli 2016 & 41 & 41 & 41 \\
\hline Agustus 2016 & 40 & 136 & 39 \\
\hline September 2016 & 474 & 233 & 474 \\
\hline
\end{tabular}

Tabel 4 Data Produksi Tas Januari - September 2016

\begin{tabular}{lccc}
\hline \multirow{2}{*}{ Bulan } & \multicolumn{3}{c}{ Jenis Tas } \\
\cline { 2 - 4 } & Tas Ransel & Tas Slempang & Tas Sekolah \\
\hline Januari 2016 & 1.680 & 1.440 & 1.776 \\
\hline Februari 2016 & 1.920 & 1.680 & 1.680 \\
\hline Maret 2016 & 1.680 & 2.112 & 1.920 \\
\hline April 2016 & 1.920 & 1.440 & 1.920 \\
\hline Mei 2016 & 1.440 & 1.200 & 1.440 \\
\hline Juni 2016 & 2.400 & 2.160 & 2.160 \\
\hline Juli 2016 & 2.400 & 2.400 & 2.400 \\
\hline Agustus 2016 & 2.160 & 2.160 & 2.160 \\
\hline September 2016 & 1.920 & 1.440 & 1.920 \\
\hline
\end{tabular}

Selanjutnya dalam rancangan Fuzzy Tsukamoto yang digunakan dalam prediksi jumlah produksi tas pada home industri Body Star Kudus di dalamnya meliputi kriteria, fuzzifikasi, pembentukan rule, defuzzifikasi, dan pengujian.

1. Kriteria

Kriteria yang digunakan dalam prediksi jumlah produksi tas menggunakan Fuzzy Tsukamoto pada home industri Body Star Kudus yaitu
a. Retur sebagai input
b. Penjualan sebagai input
c. Sisa barang sebagai input
d. Produksi sebagai output

2. Fuzzifikasi

Berdasarkan kriteria yang digunakan prediksi jumlah produksi tas menggunakan Fuzzy Tsukamoto pada home industri Body Star Kudus ada 3 variabel yang dapat dimodelkan yaitu: 
a. Kriteria Retur

Berdasarkan hasil wawancara dengan pemilik home industri Body Star Kudus retur dikatakan turun jika $<=5$, sedang antara 3 sampai 10 dan tinggi jika $>=10$. Kriteria retur dibagi menjadi 3 himpunan fuzzy, yaitu : TURUN [0 5], SEDANG [3 10] dan NAIK [5 $\infty$ ]. Himpunan TURUN dan NAIK menggunakan pendekatan fungsi keanggotaan yang berbentuk bahu, sedangkan himpunan SEDANG menggunakan pendekatan berbentuk segitiga seperti pada gambar 1 .

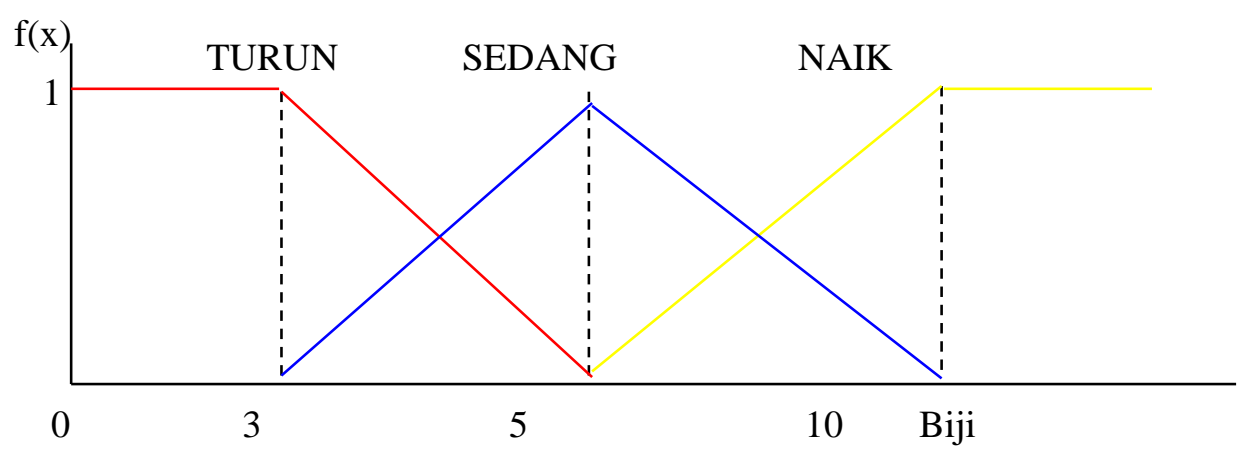

Gambar 2. Fungsi Keanggotaan pada Kriteria Retur

Fungsi keanggotaan pada kriteria retur dirumuskan sebagai berikut :

$$
\begin{aligned}
& { }^{\mu} \text { Retur TURUN }^{\left[x_{1}\right]} \begin{cases}1 & x_{1} \leq 3 \\
\frac{5-x_{1}}{2} & 3 \leq x_{1} \leq 5 \\
0 & x_{1} \geq 5\end{cases}
\end{aligned}
$$

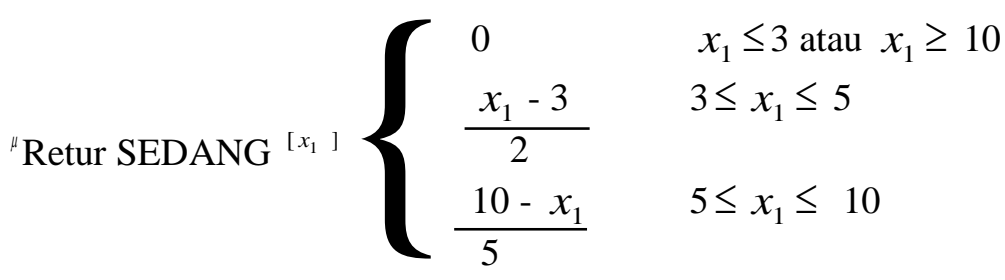

$$
\begin{aligned}
& { }^{\mu} \text { Retur NAIK }\left[x_{1}\right] \begin{cases}0 & x_{1} \leq 5 \\
\frac{x_{1}-5}{5} & 5 \leq x_{1} \leq 10 \\
1 & x_{1} \geq 10\end{cases}
\end{aligned}
$$

Fungsi keanggotaan di atas akan digunakan untuk fuzzifikasi pada retur tas slempang, tas sekolah dan tas ransel.

b. Kriteria Penjualan

Berdasarkan hasil wawancara dengan pemilik home industri Body Star Kudus penjualan dikatakan sedikit jika $<=1.250$, sedang antara 1.000 sampai 1.500 dan banyak jika 
$>=1.500$. Kriteria penjualan dibagi menjadi 3 himpunan fuzzy, yaitu : SEDIKIT [0 1250], SEDANG [1000 1500] dan BANYAK [1250 $\infty$ ]. Himpunan SEDIKIT dan BANYAK menggunakan pendekatan fungsi keanggotaan yang berbentuk bahu, sedangkan himpunan SEDANG menggunakan pendekatan berbentuk segitiga seperti pada gambar 2.

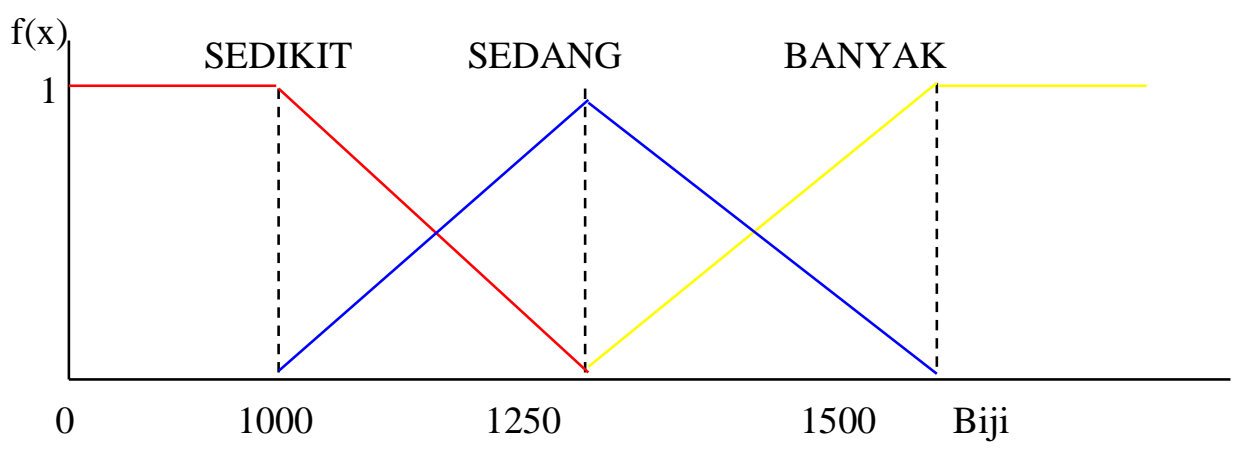

Gambar 3. Fungsi Keanggotaan pada Kriteria Penjualan

Fungsi keanggotaan pada kriteria penjualan dirumuskan sebagai berikut :

$$
\begin{aligned}
& { }^{\mu} \text { PenjualanSEDIKIT }{ }^{\left[x_{2}\right]} \begin{cases}1 & x_{2} \leq 1000 \\
\frac{1250-x_{2}}{250} & 1000 \leq x_{2} \leq 1250 \\
0 & x_{2} \geq 1250\end{cases} \\
& { }^{\mu} \text { PenjualanSEDANG }{ }^{\left[x_{2}\right.} \begin{cases}0 & x_{2} \leq 1000 \text { atau } x_{2} \geq 1500 \\
\frac{x_{2}-1000}{250} & 1000 \leq x_{2} \leq 1250 \\
\frac{1500-x_{2}}{250} & 1250 \leq x_{2} \leq 1500\end{cases} \\
& { }^{\mu} \text { Penjualan BANYAK }{ }^{\left[x_{2}\right]} \begin{cases}0 & x_{2} \leq 1250 \\
\frac{x_{2}-1250}{250} & 1250 \leq x_{2} \leq 1500 \\
1 & x_{2} \geq 1500\end{cases}
\end{aligned}
$$

Fungsi keanggotaan di atas akan digunakan untuk fuzzifikasi pada penjualan tas slempang, tas sekolah dan tas ransel.

c. Kriteria Sisa

Berdasarkan hasil wawancara dengan pemilik home industri Body Star Kudus sisa dikatakan sedikit jika $<=10$, sedang antara 10 sampai 100 dan banyak jika $>=100$. Kriteria sisa dibagi menjadi 3 himpunan fuzzy, yaitu : SEDIKIT [0 50], SEDANG [10 100] dan BANYAK $[100 \infty]$. Himpunan SEDIKIT dan BANYAK menggunakan pendekatan fungsi keanggotaan yang berbentuk bahu, sedangkan himpunan SEDANG menggunakan pendekatan berbentuk segitiga seperti pada gambar 3 . 


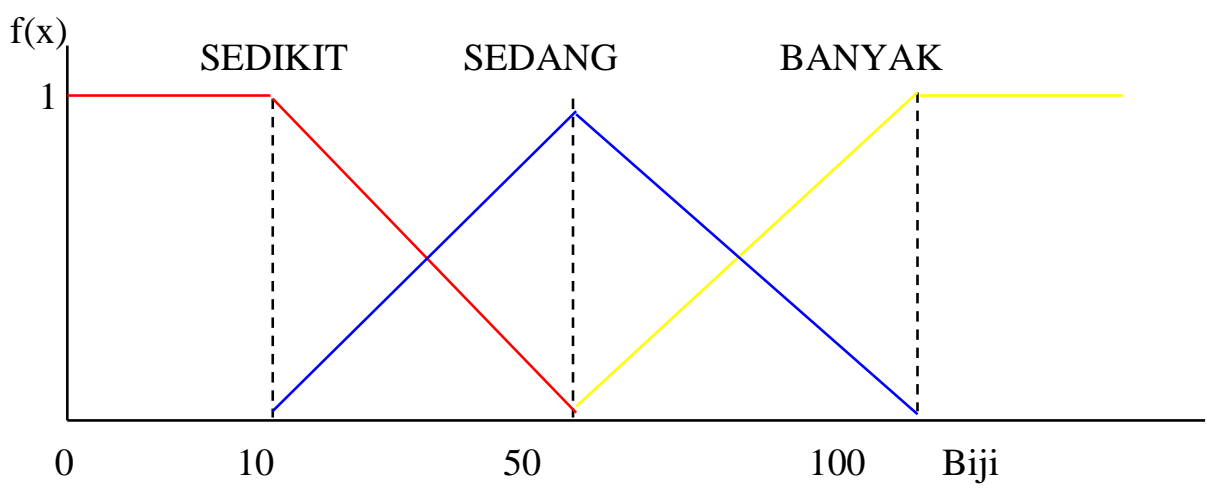

Gambar 4. Fungsi Keanggotaan pada Kriteria Sisa

Fungsi keanggotaan pada kriteria sisa dirumuskan sebagai berikut :

$$
\begin{aligned}
& { }^{\mu} \text { Sisa SEDIKIT }{ }^{\left[x_{3}\right]} \begin{cases}1 & x_{3} \leq 10 \\
\frac{50-x_{3}}{40} & 10 \leq x_{3} \leq 50 \\
0 & x_{3} \geq 50\end{cases} \\
& { }^{\mu} \text { Sisa SEDANG }{ }^{\left[x_{3}\right]} \begin{cases}0 & x_{3} \leq 10 \text { atau } x_{3} \geq 100 \\
\frac{x_{3}-10}{40} & 10 \leq x_{3} \leq 50 \\
\frac{100-x_{3}}{50} & 50 \leq x_{3} \leq 100\end{cases} \\
& { }^{\mu} \text { Sisa BANYAK }{ }^{\left[x_{3}\right]} \begin{cases}0 & x_{3} \leq 50 \\
\frac{x_{3}-50}{50} & 50 \leq x_{3} \leq 100 \\
1 & x_{3} \geq 100\end{cases}
\end{aligned}
$$

Fungsi keanggotaan di atas akan digunakan untuk fuzzifikasi pada sisa tas slempang, tas sekolah dan tas ransel.

d. Kriteria Produksi

Berdasarkan hasil wawancara dengan pemilik home industri Body Star Kudus produksi dikatakan berkurang jika $<=1.500$, sedang antara 1.000 sampai 2.000 dan bertambah jika $>=2.000$. Kriteria produksi dibagi menjadi 3 himpunan fuzzy, yaitu : BERKURANG [0 1500], SEDANG [1000 2000] dan BERTAMBAH [1500 $\infty$ ]. Himpunan BERKURANG dan BERTAMBAH menggunakan pendekatan fungsi keanggotaan yang berbentuk bahu, sedangkan himpunan SEDANG menggunakan pendekatan berbentuk segitiga seperti pada gambar 4 . 
Prediksi Jumlah Produksi Tas Pada Home Industri Body Star Kudus ...

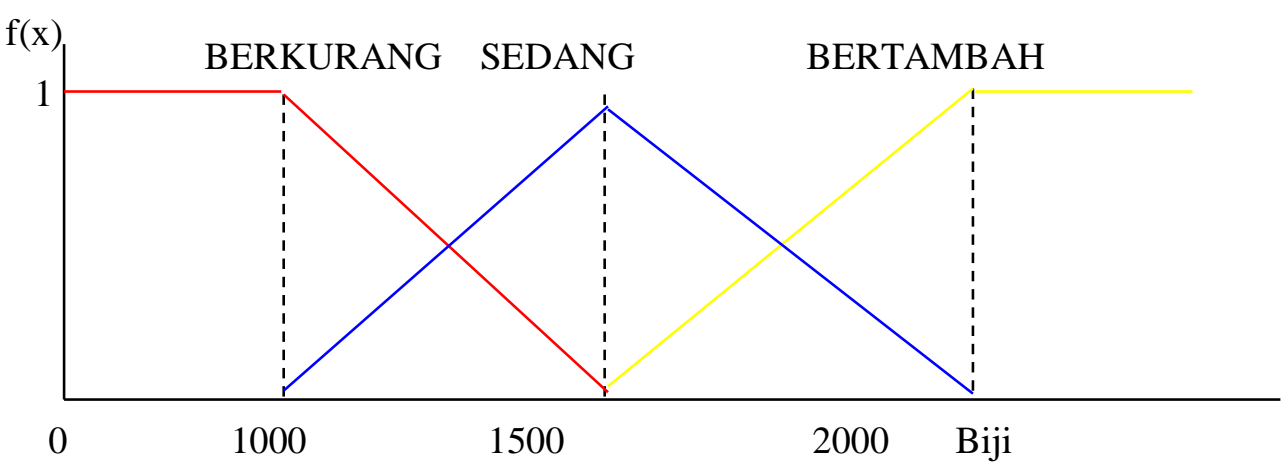

Gambar 5. Fungsi Keanggotaan pada Kriteria Produksi

Fungsi keanggotaan pada kriteria produksi dirumuskan sebagai berikut:

${ }^{\mu}$ Produksi BERKURANG ${ }^{\left[x_{4}\right]} \begin{cases}1 & x_{4} \leq 1000 \\ \frac{1500-x_{4}}{500} & 1000 \leq x_{4} \leq 1500 \\ 0 & x_{4} \geq 1500\end{cases}$

${ }^{\mu}$ ProduksiSEDANG ${ }^{\left[x_{4}\right]} \begin{cases}0 & x_{4} \leq 1000 \text { atau } x_{4} \\ \frac{x_{4}-1000}{500} & 1000 \leq x_{4} \leq 1500 \\ \frac{2000-x_{4}}{500} & 1500 \leq x_{4} \leq 2000\end{cases}$

${ }^{\mu}$ Produksi BERTAMBAH ${ }^{\left[x_{4}\right]} \begin{cases}0 & x_{4} \leq 1500 \\ \frac{x_{4}-1500}{500} & 1500 \leq x_{4} \leq 2000 \\ 1 & x_{4} \geq 2000\end{cases}$

Fungsi keanggotaan di atas akan digunakan untuk fuzzifikasi pada produksi tas slempang, tas sekolah dan tas ransel.

3. Pembentukan rule

Rule yang dihasilkan dalam prediksi jumlah produksi tas menggunakan Fuzzy Tsukamoto pada home industri Body Star Kudus seperti pada tabel 5.

Tabel 5. Rule

\begin{tabular}{ccccc}
\hline & & & IF & THEN \\
\cline { 2 - 5 } Rule & Retur & Penjualan & Sisa & Produksi \\
\hline R1 & Turun & Banyak & Banyak & Sedang \\
\hline R2 & Turun & Banyak & Sedang & Sedang \\
\hline R3 & Turun & Banyak & Sedikit & Bertambah \\
\hline R4 & Turun & Sedang & Banyak & Sedang \\
\hline R5 & Turun & Sedang & Sedang & Sedang \\
\hline R6 & Turun & Sedang & Sedikit & Bertambah \\
\hline
\end{tabular}


Muchamad Afif, Hanny Haryanto, Yuniarsi Rahayu, Edy Mulyanto

\begin{tabular}{ccccc}
\hline R7 & Turun & Sedikit & Banyak & Berkurang \\
\hline R8 & Turun & Sedikit & Sedang & Berkurang \\
\hline R9 & Turun & Sedikit & Sedikit & Sedang \\
\hline R10 & Sedang & Banyak & Banyak & Sedang \\
\hline R11 & Sedang & Banyak & Sedang & Sedang \\
\hline R12 & Sedang & Banyak & Sedikit & Bertambah \\
\hline R13 & Sedang & Sedang & Banyak & Sedang \\
\hline R14 & Sedang & Sedang & Sedang & Sedang \\
\hline R15 & Sedang & Sedang & Sedikit & Sedang \\
\hline R16 & Sedang & Sedikit & Banyak & Berkurang \\
\hline R17 & Sedang & Sedikit & Sedang & Berkurang \\
\hline R18 & Sedang & Sedikit & Sedikit & Berkurang \\
\hline R19 & Naik & Banyak & Banyak & Sedang \\
\hline R20 & Naik & Banyak & Sedang & Sedang \\
\hline R21 & Naik & Banyak & Sedikit & Sedang \\
\hline R22 & Naik & Sedang & Banyak & Sedang \\
\hline R23 & Naik & Sedang & Sedang & Sedang \\
\hline R24 & Naik & Sedang & Sedikit & Sedang \\
\hline R25 & Naik & Sedikit & Banyak & Berkurang \\
\hline R26 & Naik & Sedikit & Sedang & Berkurang \\
\hline R27 & Naik & Sedikit & Sedikit & Berkurang \\
\hline & & & &
\end{tabular}

4. Defuzifikasi

Defuzzifikasi dalam prediksi jumlah produksi tas menggunakan Fuzzy Tsukamoto pada home industri Body Star Kudus dicari dengan menggunakan rata-rata terbobot dengan rumus sebagai berikut (Rumus 1):

$$
y=\sum \frac{\mu(y) y}{\mu(y)}
$$

Dimana $y$ adalah nilai $\operatorname{crisp}$ dan $\mu(y)$ adalah derajat keanggotaan dari $y$.

5. Pengujian

Pengujian akan dilakukan terhadap data jumlah produksi dari home industri Body Star Kudus dari bulan Januari sampai September 2016 (9 bulan) menggunakan Mean Square Error (MSE) dengan rumus sebagai berikut (Rumus 2):

$$
\frac{\sum(\text { data hasil prediksi }- \text { data asli })^{2}}{\text { jumlah data }}
$$

\section{HASIL DAN PEMBAHASAN}

Dalam penelitian ini diperlukan Pengujian terhadap data jumlah produksi dari home industry Body Star Kudus dari bulan Januari sampai September 2016 (9 bulan) menggunakan Mean Square Error (MSE) yaitu
MAE
$=1.920-1.318=$
602 
Prediksi Jumlah Produksi Tas Pada Home Industri Body Star Kudus ...

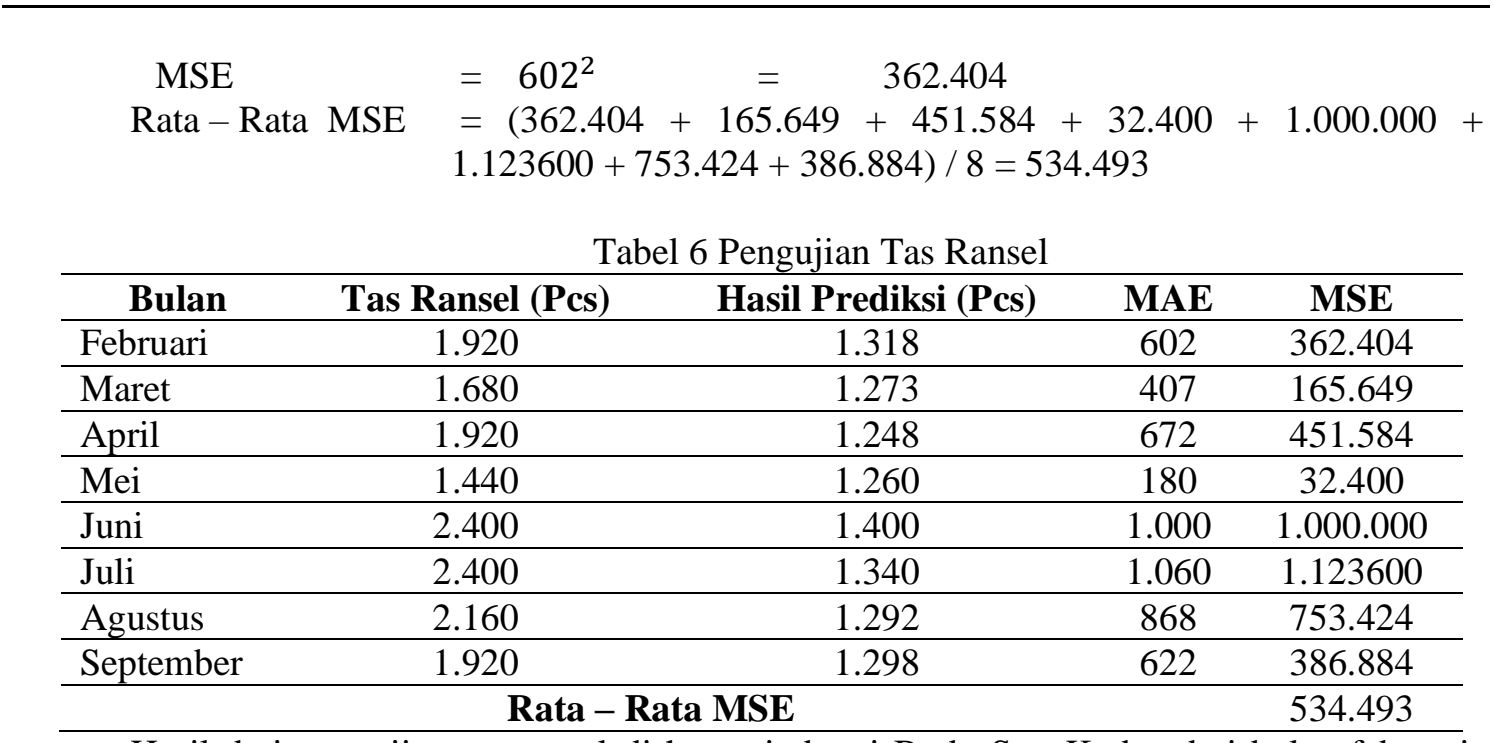

Hasil dari pengujian tas ransel di home industri Body Star Kudus dari bulan februariseptember dengan jumlah rata-rata MSE sebesar 534.493

Tabel 7 Pengujian Tas Slempang

\begin{tabular}{lcccc}
\hline \multicolumn{1}{c}{ Bulan } & Tas Slempang (Pcs) & Hasil Prediksi (Pcs) & MAE & MSE \\
\hline Februari & 1.680 & 1.357 & 323 & 104.329 \\
\hline Maret & 2.112 & 1.318 & 794 & 630.436 \\
\hline April & 1.440 & 1.500 & -60 & 3.600 \\
\hline Mei & 1.200 & 1.357 & -157 & 24.649 \\
\hline Juni & 2.160 & 1.016 & 1.144 & 1.308 .736 \\
\hline Juli & 2.400 & 1.292 & 1.108 & 1.227 .664 \\
\hline Agustus & 2.160 & 1.292 & 868 & 753.424 \\
\hline September & 1.440 & 1.260 & 180 & 32.400 \\
\hline \multicolumn{5}{c}{ Rata - Rata MSE } \\
\hline
\end{tabular}

Hasil dari pengujian tas slempang di home industri Body Star Kudus dari bulan februari-september dengan jumlah rata-rata MSE sebesar 510.655

Tabel 8 Pengujian Tas Sekolah

\begin{tabular}{lcccc}
\hline \multicolumn{1}{c}{ Bulan } & Tas Sekolah (Pcs) & Hasil Prediksi (Pcs) & MAE & MSE \\
\hline Februari & 1.680 & 1.290 & 390 & 152.100 \\
\hline Maret & 1.920 & 1.500 & 420 & 176.400 \\
\hline April & 1.920 & 1.500 & 420 & 176.400 \\
\hline Mei & 1.440 & 1.340 & 100 & 10.000 \\
\hline Juni & 2.160 & 1.400 & 760 & 577.600 \\
\hline Juli & 2.400 & 1.215 & 1.185 & 1.404 .225 \\
\hline Agustus & 2.160 & 1.292 & 868 & 753.424 \\
\hline September & 1.920 & 1.315 & 605 & 366.025 \\
\hline \multicolumn{5}{c}{ Rata - Rata MSE } \\
\hline
\end{tabular}

Hasil dari pengujian tas sekolah di home industri Body Star Kudus dari bulan februariseptember dengan jumlah rata-rata MSE sebesar 452.022 


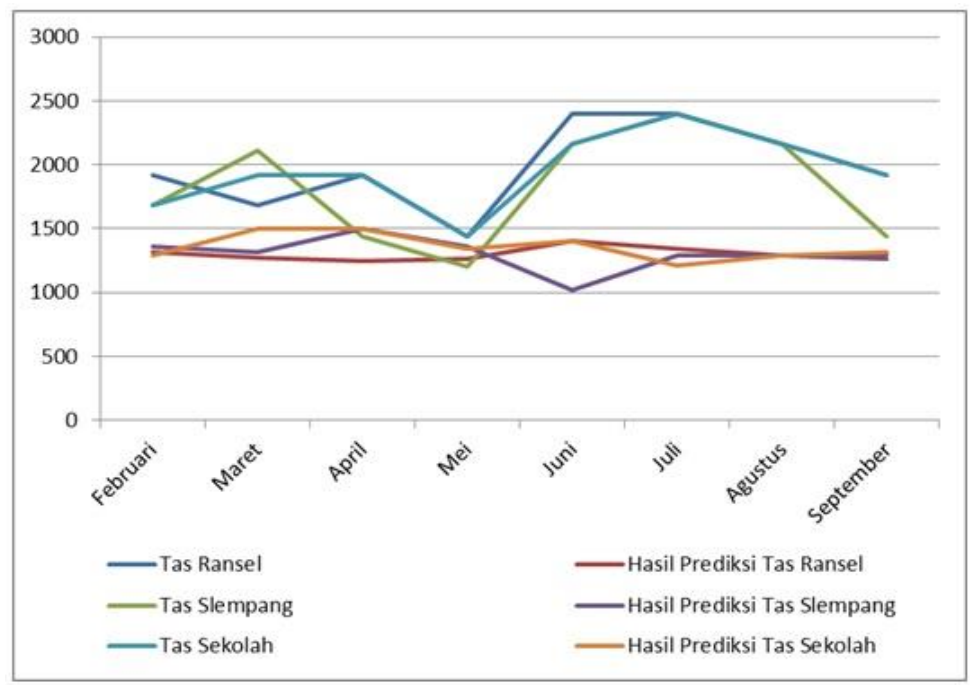

Gambar 5 Grafik Produksi dan Hasil Prediksi

Dari grafik produksi dan hasil prediksi diatas berisi tentang bulan februari-september selanjutnya warna biru menunjukan data tas ransel, warna hijau menunjukan data tas slempang, dan warna biru muda menunjukan data tas sekolah sedangkan warna merah menunjukan hasil prediksi tas ransel, warna ungu menunjukan hasil prediksi tas slempang dan warna orange menunjukan hasil prediksi tas sekolah.

\section{KESIMPULAN}

Hasil dari penelitian yang telah dikerjakan oleh peneliti, maka dapat ditarik kesimpulan bahwa prediksi yang dihasilkan memiliki akurasi yang kurang bagus disebabkan karena sulitnya penentuan parameter input yang tepat. Hal ini diketahui ketika dilakukan pengubahan terhadap parameter input maka juga terjadi perubahan terhadap akurasi.

\section{SARAN}

Untuk meningkatkan kinerja serta menyempurnakan penelitian yang telah dibuat ini, maka peneliti memberikan saran sebagai berikut :

a. Dalam perhitungan produksi dengan menggunakan model Fuzzy Tsukamoto dapat memperbanyak pilihan kriteria yang diajukan sistem yang bersifat dinamik yang terdiri dari variabel input kriteria Fuzzy.

b. Pengembangan selanjutnya, sistem diharapkan dapat menggunakan metode Fuzzy Tsukamoto dengan metode yang lain seperti Fuzzy mamdani untuk meningkatkan akurasi.

\section{DAFTAR PUSTAKA}

[1] Achmad Shergian; Hari purnomo, "Desain Tas Ransel Pria Berbahan Limbah Kantong Plastik Dengan Metode Quality Function Deployment," Teknik Industri Universitas Islam Indonesia, Yogyakarta, vol. 2, no. 2337, pp. 393-401, 2013.

[2] Rizal Arief Hidayat, "Strategi Pengembangan Industri Kecil Tas Di Kecamatan Jati Kabupaten Kudus," Fakultas Ekonomi Universitas Negeri Semarang, vol. 2, no. 4, pp. 148-158, 2013.

[3] Darni Anggraini, "Perbandingan Model Chen Dan Model Lee Pada Metode Fuzzy Time 
Series Untuk Prediksi Harga Emas," Teknik Informatika, Universitas Islam Negeri Sultan Syarif Kasim Riau, Pekanbaru, 2012.

[4] M. . Riyadi Yudha Wiguna, Hanny Haryanto, "Sistem berbasis aturan menggunakan logika fuzzy tsukamoto untuk prediksi jumlah produksi roti pada cv. gendis bakery," Teknik Informatika Universitas Dian Nuswantoro, Semarang 2015.

[5] M. P. Pratiwi, "Analisa Kelayakan Truk Pengangkut Material Alam Pt . Arga Wastu Sluke - Rembang," Teknik Informatika Universitas Dian Nuswantoro, Semarang, pp. 1-5, 2010.

[6] D. Mahasati and H. A. Wibawa, "Penerapan Sistem Inferensi Fuzzy Dalam Menentukan Prioritas Heuristik Pada Aplikasi Game Fighting Sederhana," Teknik Informatika Universitas Diponegoro, Semarang, vol. 2, pp. 15-20, 2012. 